Research Article

\title{
The effect of problem-based learning integrated with concept mapping technique on students' learning activities
}

\author{
Siti Murdiyah a,1,* ${ }^{*}$ S. Suratno a,2, Arina Firdausi Nur Ardhan a,3 \\ a Department of Biology Education, Faculty of Teacher Training and Education, Universitas Jember, J. Kalimantan 37, Krajan Timur, \\ Sumbersari, Jember, East Java 68121, Indonesia. \\ murdiyah_st.fkip@unej.ac.id *; 2 suratno.fkip@unej.ac.id; 3 arinafirdausi16@gmail.com \\ ${ }^{*}$ Corresponding author
}

\begin{tabular}{|c|c|}
\hline ARTICLE INFO & ABSTRACT \\
\hline $\begin{array}{l}\text { Article history } \\
\text { Received July 31, 2019 } \\
\text { Revised October 20, } 2019 \\
\text { Accepted February 29, } 2020 \\
\text { Published March 31, } 2020 \\
\text { Keyword } \\
\text { Concept map } \\
\text { Problem-based learning } \\
\text { Student activities }\end{array}$ & 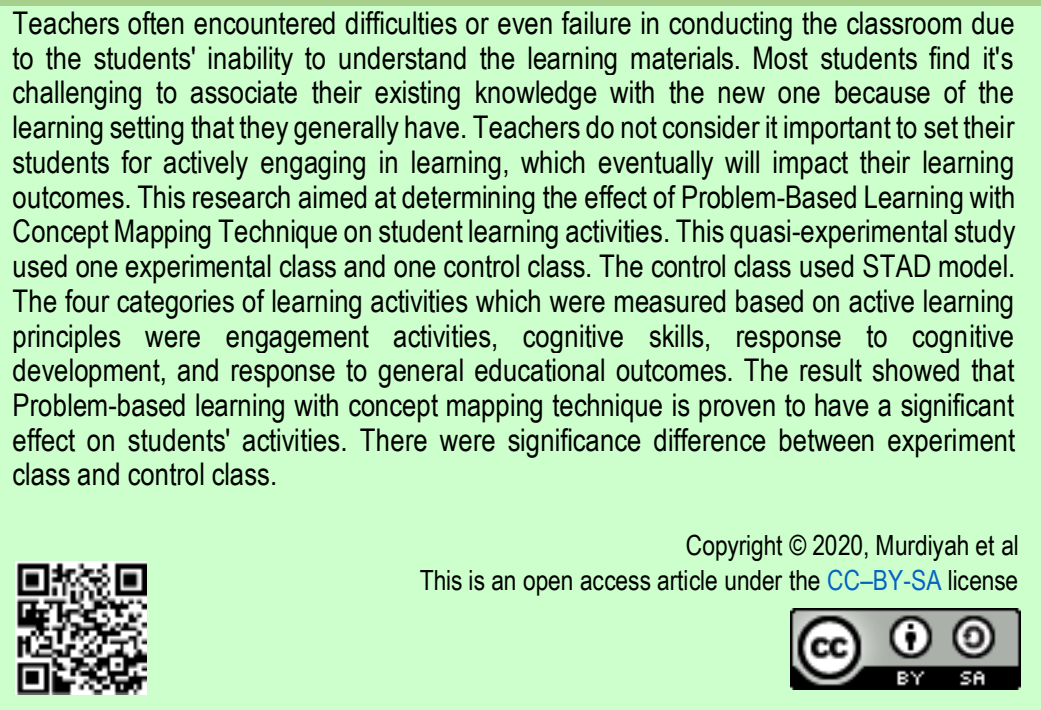 \\
\hline $\begin{array}{l}\text { How to cite: Murdiyah, } \\
\text { mapping te } \\
\text { doi.org/10. }\end{array}$ & $\begin{array}{l}\text { \& Ardhan, A. F. N. (2020). The effect of problem-based learning integrated with concep } \\
\text { dents' learning activities. JPBI (Jurnal Pendidikan Biologi Indonesia), 6(1), 39-46. doi: https:I } \\
9113\end{array}$ \\
\hline
\end{tabular}

\section{INTRODUCTION}

Education is a systematic process that aims to improve human dignity holistically. The point is to actualize the three most basic dimensions of humanity, including 1) attitude or affective which is reflected in the quality of faith and piety, 2) cognitive which is reflected in logical and intellectual capacity, 3) psychomotor which is reflected in the ability to develop technical skills and soft skills (Widodo, 2016). Those are the three domains of learning that all teachers must know about them and be able to use them in each lessons. Learning in each level of education must be interactive, fun, challenging, and motivate students to participate actively (Lau \& Lee, 2015). This type of class will provide sufficient space for initiative and creativity following students' development, talents, and interests (Lian, Kristiawan, \& Fitriya, 2018). Hence, it is fair to say that teaching designed by the teacher must be oriented to student activities (Gore et al., 2017). Active learning evidently promotes the learning process for all students. Using some of active learning approaches are also an effective tool in making the 
classroom more inclusive (Molenda, 2015; Yang, Zhang, Chen, Zhang, \& Chen, 2017). Learning that advocates active-involvement focus more on developing students' skills than on transmitting information and therefore require higher-order thinking (Koyama \& Mizokamil, 2019). Student activity is student engagement in the form of attitudes, attention, and activities. Through correct involvement, students are allowed to obtain and shape a new set of competencies and skills (Surani \& Suryani, 2015).

As a tool to creates the next generation, education plays an important role in shaping up the future of a nation. However, the quality of education nowadays is still unsatisfying. Learning objectives still cannot be completed properly (Yanuarta, Waluyo, \& Suratno, 2014). In teaching and learning activities, students generally only take lessons passively (Magana, Vieira, \& Boutin, 2018). Students very rarely engage in contextual setting, nor even applying their comprehension on day to day situation. The teacher's role is overly dominating, instructional interactions only go in one direction. The instructional instruction such as instruction to a quiet in classroom, students tend to not asking a questions and being shame to express their opinions. Students also lose the opportunity to be creative, not enthusiastic to follow the lesson, and difficult to express ideas and creativity (Rahmadani, Harahap, \& Gultom, 2017).

One of the indicators causing learning difficulties is the chosen of delivery method. Determination of strategies for teaching should follow psychological reviews, the nature of the learning material, tasks to be given and expected learning situations (Forman, Ramirez-DelToro, Brown, \& Passmore, 2017). This pedagogical skill helps teachers to accomplish his/her learning objectives. The main weaknesses system among the three shortcomings of the educational system in developing countries is incorrect selection of learning strategy. The most chosen teaching method has been the direct method or expository learning or plain lecturing (Chatila \& Husseiny, 2016). Teachers consider this method as the most convenient since it doesn't require many preparations and time-saving. The conventional strategy only emphasizes students to memorize in each of their learning. It may deliver students to get high grades in every level of education, but unfortunately, the grade unable to reflect the real student knowledge achievements.

One of the solutions to overcome this problem is Problem-based Learning (PBL), this model was used to implement a learning model that can provide a change of attitude for students when the learning process takes place (Khoiriyah and Husamah, 2018; Lukitasari, Purnamasari, Utami, \& Sukri, 2019). PBL can be an alternative to overcome obstacles in achieving maximum learning outcomes. PBL is an appropriate learning strategy in line with the 201-Curriculum (Sofyan \& Komariah, 2016). PBL also congruent with the concept of constructivism learning, which is to foster a creative and collaborative spirit, develop high-level thinking skills, increase understanding, increase learning independence, facilitate problem-solving, and enhance learning achievement (Mwanda, 2017).

PBL has been proven to influence motivation, critical thinking, problem-solving skill, metacognition, and learning achievement (Abdurrozak et al., 2016; Danial, 2010; Kamble \& Tembe, 2013). Moreover, some previous studies on the effect of PBL on learning activities have been done (Dewi, Akbari, \& Nugroho, 2019; Safitri, Yennita, and Idrus, 2018) and most of those study measured activity based on the learning experiences that mostly emphasized on physical activity and measured using a self-developed instrument. One disadvantage of PBL is to cause misconceptions due to students' self-directed learning (Arahmat, Suratno, \& Wahono, 2017). Mapping concepts are able to overcome these PBL weaknesses through the relationships and linkages between concepts that are clearly described (Juhii, 2017; Negoro, Hidayah, Subali, \& Rusilowati, 2018). Making a concept map aims to instill materials and as an indicator to the extent of the students' understanding (Sasinggala, 2017). Concept mapping is a graphics technique showing information that is hierarchically arranged and has connections between concepts in the form of graphics, images, or illustrations (Juhji, 2017).

In this study used PBL with validated-standardized instruments to measure student activity based on active learning principles. The instruments not only consist of physical activity but also consist of student's mental engagement and student's response toward their learning. There are many sources, such as CLASSE, Copus, TDOP, or Motivation and Study Process Questionnaire, are available to use by teachers, educators, and researchers with license to validate this study. Furthermore, in this study also employs concept mapping as a technique in presenting the results of investigations during the learning process. The implementation of concept maps in the learning provides diverse benefits, one of them is to increase the activeness of students to ask questions and train students' creative thinking (Ogonnaya \& Abonyi, 2016). The function of concept mapping is a tool to investigate what students already know in the form of concepts and used to measure the level of understanding as one of the learning achievement (Maurisa \& Abdullah, 2016). Moreover, to study biology science appropriately, and science in general, a good cognitive structure is needed. The cognitive structure is 
the organization of information that includes facts, concepts, and generalizations that have been studied and remembered by students. Therefore, this study aimed to measure the effect of problem-based learning and concept map on students' learning activities. This research will be very useful to be applied in schools, to improve students' abilities in dealing with learning problems by using concept maps.

\section{METHOD}

This research design was a non-equivalent control group design, sort of quasi-experimental studies. Two classes were involved as samples in this study. Indeed, the Problem-based Learning (PBL) model with concept mapping technique was performed as the experimental class. Whereas, the Student Team Achievement Division (STAD) model was applied as a control, which was a method belongs to the cooperative model that frequently uses in the school. The population of this study was the eleventh science grade students of SMAN 1 Arjasa, Jember-East Java. The sample of this study were both the class of XI IPA 3 as the experimental group and the class of XI IPA 5 as the control group. The samples were chosen by purposive random sampling. Data collection was carried out by using questionnaires

Student activities in this study were observed using a modified Classes Student Instrument (Oumet \& Smallwood, 2005) and CLEAP (Savory, Goodburn, \& Kellas, 2012). There were four domains of student activities being measured, namely engagement activities, cognitive skills, responses to cognitive development, and responses to general-education outcomes. These four domains were chosen because the items represent fundamental aspects in determining student learning activities such as motivation, awareness for learning, mental activities or thinking activities that occur while learning. Moreover, in total there were 49 items was observed in the questionnaire. Students filled out the questionnaire after the learning period was over. The differences in each domain or category of learning activity for treatment class or control class analyzed using a t-test for independent samples.

\section{RESULTS AND DISCUSSION}

The data were collected from sixty-sixth secondary school students. They came from thirty-four students of the experiment class and thirty-two students from the control class. Table 1 presents the average scores of all measurements.

Table 1. The average scores

\begin{tabular}{cccccc}
\hline \multirow{2}{*}{ No } & Class & $\begin{array}{c}\text { Engagement } \\
\text { activities }\end{array}$ & Cognitive skills & $\begin{array}{c}\text { Response to cognitive } \\
\text { development }\end{array}$ & $\begin{array}{c}\text { Response to general } \\
\text { educational outcomes }\end{array}$ \\
\hline 1 & Experiment & $81,2 \pm 6,7$ & $79,9 \pm 6,1$ & $81,6 \pm 8,1$ & $78,7 \pm 6,9$ \\
2 & Control & $51,3 \pm 8,1$ & $52,2 \pm 9,5$ & $53,3 \pm 8,1$ & $51,2 \pm 9,1$ \\
\hline
\end{tabular}

Table 1 shows the average scores of the experimental class are higher than the control class. The students' response to cognitive development was the highest (81.6), while the student response to general-educational outcomes got the lowest of the average score (78.7). The overall result was presented in the Figure 1.

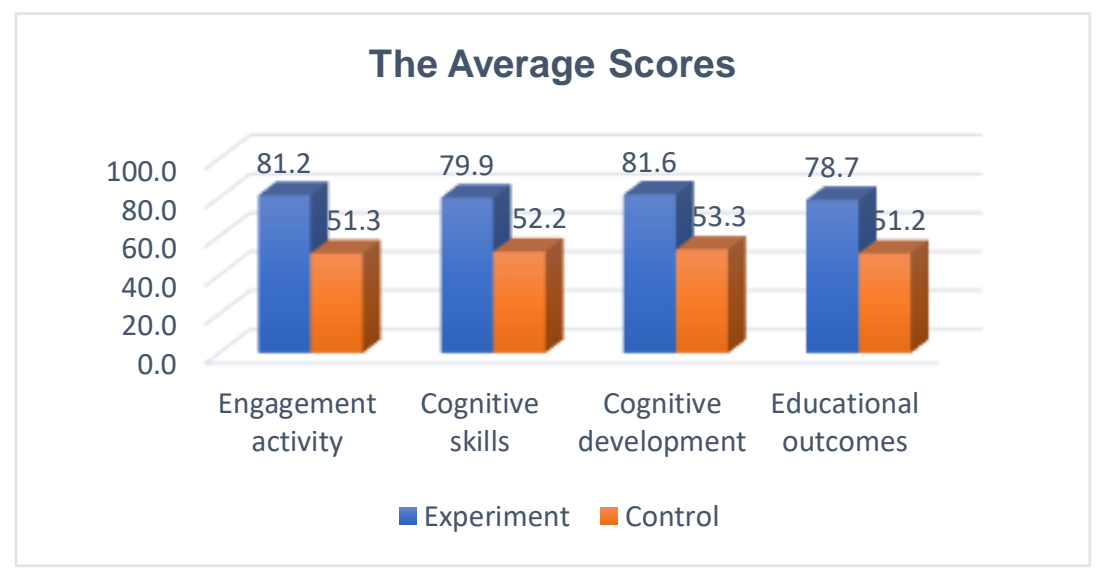

Figure 1. The average scores of four domains of student activities 
The score for each domain was then analyzed using an independent-samples t-test, the result was as follows.

\section{Engagement activities}

The result of the independent sample t-test was described in Table 2 between the experimental class and the control class shows that there is a significant difference in the engagement activities $(p=0.000)$, by the mean difference of 30.45. This result was in line with the result of Faridah, Ramlah, Norhasbiah, and Umar (2016); and also Tarmizi, Tarmizi, Lojinin, and Mokhtar (2010) stated that problem-based learning is a teaching approach that encourage students to participate actively in the process of learning. Problem-based learning was considered to improve student engagement because it has several advantages. One of advantages is the students are involved in learning activities, then the knowledge could be well absorbed (Khoiriyah \& Husamah, 2018). Moreover, the students are trained to be able to work collaboratively, and they can attain any solutions from various resources. Each student actively participates in the learning process and they were not just listening. The students engaged in different activities such as discussion, planning, gain information and produce solutions (Dewi et al., 2019).

Table 2. Independent samples t-test of engagement activities

\begin{tabular}{|c|c|c|c|c|c|c|c|c|c|c|}
\hline & & \multicolumn{2}{|c|}{$\begin{array}{l}\text { Levene's test for } \\
\text { equality of variances }\end{array}$} & \multicolumn{7}{|c|}{ t-test for equality of means } \\
\hline & & \multirow[t]{2}{*}{$\mathbf{F}$} & \multirow[t]{2}{*}{ Sig. } & \multirow[t]{2}{*}{$t$} & \multirow[t]{2}{*}{ df } & \multirow{2}{*}{$\begin{array}{l}\text { Sig. }(2- \\
\text { tailed) }\end{array}$} & \multirow{2}{*}{$\begin{array}{c}\text { Mean } \\
\text { difference }\end{array}$} & \multirow{2}{*}{$\begin{array}{l}\text { Std. error } \\
\text { difference }\end{array}$} & \multicolumn{2}{|c|}{$\begin{array}{l}95 \% \text { confidence interval of } \\
\text { the difference }\end{array}$} \\
\hline & & & & & & & & & Lower & Upper \\
\hline \multirow[t]{2}{*}{ Score } & $\begin{array}{l}\text { Equal variances } \\
\text { assumed }\end{array}$ & 1.675 & .200 & 16.918 & 64 & .000 & 30.45349 & 1.80009 & 26.85740 & 34.04958 \\
\hline & $\begin{array}{l}\text { Equal variances } \\
\text { not assumed }\end{array}$ & & & 16.839 & 61.250 & .000 & 30.45349 & 1.80848 & 26.83751 & 34.06947 \\
\hline
\end{tabular}

The term student engagement was used to describe the degree of attention, curiosity, interest, optimism, and passion that students show when they are learning (Mandernach, 2015; Savory et al., 2012). Students are engaged when they care about what's going on in the classroom. This interest potentially makes the students stay motivated to learn and get progress in their studies. Cultivating the intrinsic motivation is one of PBL's goals (Hmelo-Silver, 2004). The goals of PBL include helping students developing their flexible knowledge, effective problem-solving skills, self-directed learning skills, collaboration skills, and intrinsic motivation.

Strengthening PBL with other methods would amplify its effect (Faridah et al., 2016; Hardjito, 2010; Kurniyawati, Na'im, \& Fawait, 2019). Indeed, the concept mapping is a meta-learning strategy that can be used to develop students' capacity to learn independently, a term that parallel with the objectives of PBL (Chiou, 2008; Johnstone \& Otis, 2006). Furthermore, concept mapping is utilized as a useful tool for reinforcing meaningful learning. This is achieved in part by facilitating knowledge capture and integration as well as enriching meta-cognitive skills and student engagement. Brame (2016) stated that concept mapping is one of the learning techniques that supports active learning. The technique helps students to examine and strengthen their concept organization, recheck any misconceptions, and ultimately increase their understanding.

\section{Cognitive skills}

The result of the independent sample t-test showed that there is a significant difference in cognitive skills between experiment class and the control class (p. 0.000) with the mean difference of 27.7 (Table 3).

Table 3. Independent samples t-test of cognitive skills

\begin{tabular}{|c|c|c|c|c|c|c|c|c|c|c|}
\hline & \multicolumn{2}{|c|}{$\begin{array}{l}\text { Levene's test for } \\
\text { equality of variances }\end{array}$} & \multicolumn{7}{|c|}{ t-test for equality of means } \\
\hline & & \multirow{2}{*}{$\mathrm{F}$} & \multirow{2}{*}{ Sig. } & \multirow{2}{*}{$t$} & \multirow[t]{2}{*}{ df } & \multirow{2}{*}{$\begin{array}{l}\text { Sig. (2- } \\
\text { tailed) }\end{array}$} & \multirow{2}{*}{$\begin{array}{c}\text { Mean } \\
\text { difference }\end{array}$} & \multirow{2}{*}{$\begin{array}{l}\text { Std. error } \\
\text { difference }\end{array}$} & \multicolumn{2}{|c|}{$\begin{array}{c}95 \% \text { Confidence interval of } \\
\text { the difference }\end{array}$} \\
\hline & & & & & & & & & Lower & Upper \\
\hline \multirow[t]{2}{*}{ Score } & $\begin{array}{l}\text { Equal variances } \\
\text { assumed }\end{array}$ & 9.463 & .003 & 14.102 & 64 & .000 & 27.70551 & 1.96468 & 23.78062 & 31.63041 \\
\hline & $\begin{array}{l}\text { Equal variances } \\
\text { not assumed }\end{array}$ & & & 13.923 & 52.415 & .000 & 27.70551 & 19.8987 & 23.71330 & 31.69772 \\
\hline
\end{tabular}

This result supported the studies by Bayat and Tarmizi (2012) and also Safitri, Bachtiar, and Rukman (2018) that PBL has positive effects on procedural knowledge and mental load during the learning process. Cognitive 
skill is defined as a general mental capability involving reasoning, problem-solving, planning, abstract thinking, complex idea comprehension, and learning from experience (Ones, Dilchert, \& Viswesvaran, 2012). In other words, a set of competencies formulated by Bloom is needed to process information gaining, ideas exchanging to become a solutive and useful conclusion. The whole process in problem-solving and concept mapping requires cognitive skills. The verbal interaction during group discussion, both in the experiment class and the control class, represents the construction of concepts, data exploration, reasoning, evaluating and reevaluating, also theory building. Even the lower level of thinking, such as recalling was used regularly in making conclusions.

Concept mapping is a technique to address both what students know and how students organize their knowledge (Chiou, 2008). This technique provides a particular learning experience where students are intellectually empowered through their learning. In the process of constructing the map, students are free to use their scheme to make connections and create links. This such of freedom requires creativity and also boosts confidence to take responsibility for their own learning.

\section{Response to cognitive development}

The result of the independent sample t-test was described in Table 4 between the experiment class and the control class shows that there is a significant difference in students' responses to cognitive development $(p=0.000)$ by the mean difference of 28.3 .

Table 4. Independent samples t-test of response to cognitive development

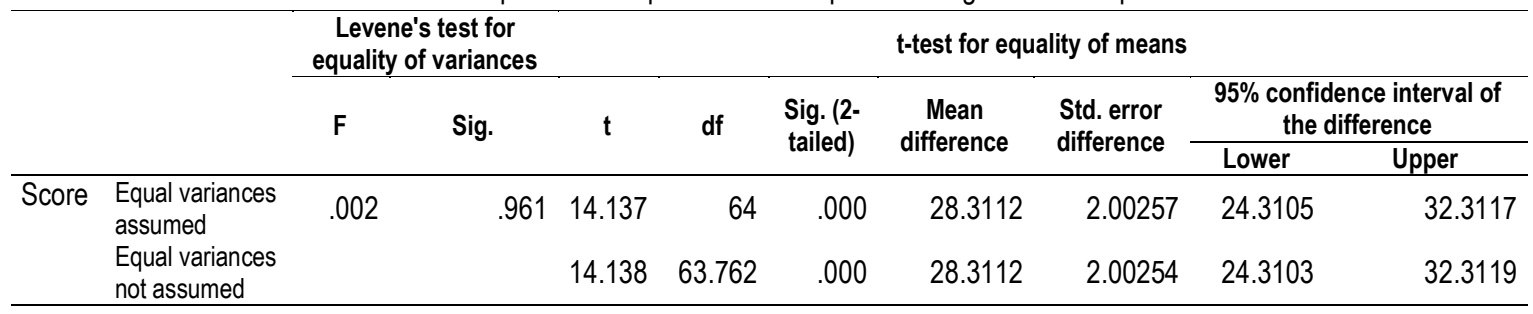

Cognition refers to capabilities, including memory, thinking, reasoning, spatial processing, problem-solving, language, and perception. Theories of cognitive development aim to explain the changing mechanisms rather than merely to describe the capabilities of students based on their ages or level of education (Richland, Frausel, and Begolli, 2016). The analysis of a mental process changing requires a complicated psychological approach. The more practical approach is inferring from observable behavior through student responses (Gijbels, Dochy, Van den Bossche, and Segers, 2005; Rotgans and Schmidt, 2011). There are some expressions such as bored, happy, passionate, interested, and attracted, has considered being emotional involvement in the form of appreciation of feelings, values, or attitudes. Moreover, by an assumption that students are being honest in expressing their situation, students' response illustrates the size of learning impact on their intellectual development.

The efforts that showed by students either to understand a concept or to finish a task, sometimes only superficial activities. Students were physically active, such as moving to other groups, searching for learning sources, reading, or having peered talks (Richland, Frausel, and Begolli, 2016). However, after a long period of the lesson or other reasons, those activities were only mechanical activities, without having a profound impact on the students' learning process. The measuring of student responses, the teacher knew certainly the extent to which learning brings any changes to students' mental processes. Furthermore, If students realized the positive impact of their learning, and they are satisfied with it, they would voluntarily engage in a new problem, and eventually, the cycle of PBL starts all over again (Rotgans and Schmidt, 2011).

Problem based learning is a form of cognitive-constructivist learning. Students develop a concept about phenomena described in the intended problem with the help of their peers. Moreover, self-directed learning activities such as reading or browsing well serve to test students' initial concept. Thereby, PBL could elaborate, change, and depth the students' understanding of the topic (Dewi et al., 2019; Rotgans and Schmidt, 2011). The formation of new knowledge is a constructive process involving both the previous knowledge and the drive to create new meanings, as well as a new way to represent these meanings. Therefore, this function is supported by a concept mapping. However, the creative capacity did not favor all of the students. Some students tend to finish their mapping tasks without investing a proper amount of effort. It is important for the teacher to detect this kind of symptom and cracks it. 


\section{Response to general educational outcomes}

The result of the independent sample t-test showed that there is a significant difference in students' responses to other educational outcomes between experiment class and the control class (p. 0,000) with the mean difference of 27,5 (Table 5).

Table 5. Independent samples t-test of response to general educational outcomes

\begin{tabular}{|c|c|c|c|c|c|c|c|c|c|c|}
\hline & & \multicolumn{2}{|c|}{$\begin{array}{l}\text { Levene's test for } \\
\text { equality of variances }\end{array}$} & \multicolumn{7}{|c|}{ t-test for equality of means } \\
\hline & & \multirow[t]{2}{*}{$F$} & \multirow[t]{2}{*}{ Sig. } & \multirow[t]{2}{*}{$t$} & \multirow[t]{2}{*}{ df } & \multirow{2}{*}{$\begin{array}{l}\text { Sig. }(2- \\
\text { tailed) }\end{array}$} & \multirow{2}{*}{$\begin{array}{c}\text { Mean } \\
\text { difference }\end{array}$} & \multirow{2}{*}{$\begin{array}{l}\text { Std. error } \\
\text { difference }\end{array}$} & \multicolumn{2}{|c|}{$\begin{array}{l}95 \% \text { confidence interval of } \\
\text { the difference }\end{array}$} \\
\hline & & & & & & & & & Lower & Upper \\
\hline \multirow[t]{2}{*}{ Score } & $\begin{array}{l}\text { Equal variances } \\
\text { assumed }\end{array}$ & 2.472 & .121 & 13.914 & 64 & .000 & 27.5037 & 1.97663 & 23.555 & 31.4525 \\
\hline & $\begin{array}{l}\text { Equal variances } \\
\text { not assumed }\end{array}$ & & & 13.797 & 57.588 & .000 & 27.5037 & 1.99340 & 23.513 & 31.4945 \\
\hline
\end{tabular}

Educational outcomes in this study were inferred from Savory et al (2012) that the outcomes are more emphasized on student responses that are projected in the future interests. Some of the character building such as openness, academic habit, self-confidence, decision-making skill, sensitivity towards social issues, collaborative, and communicative skills are asked in the questionnaire with specific addition as how those characteristics will help students in pursuing their career. The findings implied that students who more actively engaged in their studies have a higher awareness of their future careers. The student eventually care about their school performance as it will affect professional life. Education prepares for the future. Brame (2016) and Van Amburgh, Devlin, Kirwin, and Qualters (2007) stated that students exposed to active learning are likely more successful in life than the student who didn't exposed to active learning. The approaches to learning are central learner cognitive attributes that significantly shape the nature of engagement with higher education and correlate with academic performance and also continuing professional development.

\section{CONCLUSION}

Problem-based learning with concept mapping technique is proven to have a significant effect on students' activities based on the four domains of active learning that showed a significance difference between the experiment class and the control class.

\section{REFERENCES}

Abdurrozak, R., Jayadinata, A. K., \& Isro'atun. (2016). Pengaruh model problem based learning terhadap kemampuan berpikir kreatif siswa. Jurnal Pena Ilmiah, 1(1), 871-880. doi: https://doi.org/10.23819/pi. v111.3580

Arahmat, Y., Suratno, S., \& Wahono, B. (2017). The effect of problem based learning model with mind mapping technique on biology learning achivement. Pancaran Pendidikan, 6(2), 125-132. doi: https://doi.org/10. 25037/pancaran.v6i2.39

Bayat, S., \& Tarmizi, R. A. (2012). Effects of problem-based learning approach on cognitive variables of university students. Procedia-Social and Behavioral Sciences, 46, 3146-3151. doi: https://doi.org/10.10 16/j.sbspro.2012.06.027

Brame, C. (2016). Active learning. Retrieved December 7, 2019, from https://cft.vanderbilt.edu/

Chatila, H., \& Husseiny, F. Al. (2016). Effect of cooperative learning strategy on students' acquisition and practice of scientific skills in biology. Journal of Education in Science, Environment and Health, 3(1), 8888. doi: https://doi.org/10.21891/jeseh.280588

Chiou, C.-C. (2008). The effect of concept mapping on students' learning achievements and interests. Innovations in Education and Teaching International, 45(4), 375-387. doi: https://doi.org/10.1080/147 03290802377240

Danial, M. (2010). Pengaruh strategi PBL terhadap keterampilan metakognisi dan respon mahasiswa. Chemica: Jurnal IImiah Kimia dan Pendidikan Kimia, 11(2), 1-10. doi: https://doi.org/10.35580/chemica.v11i2.487

Dewi, E. H. P., Akbari, S., \& Nugroho, A. A. (2019). Peningkatan aktivitas dan hasil belajar biologi melalui model problem based learning (PBL) pada materi pencemaran lingkungan siswa kelas X SMA Negeri 1 Jatisrono. Journal of Biology Learning, 1(1), 53-62. Retrieved from http://journal.univetbantara.ac.id/ 
index.php/JBL/article/view/251

Faridah, S., Ramlah, M., Norhasbiah, U., \& Umar, A. (2016). The effect of project-based learning against students' engagement. International Journal of Development Research, 6, 6891-6895. Retrieved from https://www.researchgate.net/publication/296672247

Forman, E. A., Ramirez-DelToro, V., Brown, L., \& Passmore, C. (2017). Discursive strategies that foster an epistemic community for argument in a biology classroom. Learning and Instruction, 48, 32-39. doi: https://doi.org/10.1016/j.learninstruc.2016.08.005

Gijbels, D., Dochy, F., Van den Bossche, P., \& Segers, M. (2005). Effects of problem-based learning: A metaanalysis from the angle of assessment. Review of Educational Research, 75(1), 27-61. doi: https://doi. org/10.3102/00346543075001027

Gore, J., Lloyd, A., Smith, M., Bowe, J., Ellis, H., \& Lubans, D. (2017). Effects of professional development on the quality of teaching: Results from a randomised controlled trial of quality teaching rounds. Teaching and Teacher Education, 68, 99-113. doi: https://doi.org/10.1016/j.tate.2017.08.007

Hardjito, D. (2010). The use of scaffolding approach to enhance students' engagement in learning structural analysis. International Education Studies, 3(1), 1-11. doi: https://doi.org/10.5539/ies.v3n1p130

Hmelo-Silver, C. E. (2004). Problem-based learning: What and how do students learn? Educational Psychology Review, 16(3), 235-266. doi: https://doi.org/10.1023/B:EDPR.0000034022.16470.f3

Johnstone, A. H., \& Otis, K. H. (2006). Concept mapping in problem based learning: A cautionary tale. Chem. Educ. Res. Pract., 7(2), 84-95. doi: https://doi.org/10.1039/B5RP90017D

Juhji, J. (2017). Upaya mengatasi miskonsepsi siswa pada materi sistem saraf melalui penggunaan peta konsep. Formatif: Jurnal IImiah Pendidikan MIPA, 7(1), 33-39. doi: https://doi.org/10.30998/formatif.v7i1. 1200

Kamble, S. K., \& Tembe, B. L. (2013). The effect of use of concept maps on problem solving performance and attitude in mechanical engineering course. Procedia - Social and Behavioral Sciences, 83, 748-754. doi: https://doi.org/10.1016/j.sbspro.2013.06.141

Khoiriyah, A. J., \& Husamah, H. (2018). Problem-based learning: Creative thinking skills, problem-solving skills, and learning outcome of seventh grade students. JPBI (Jurnal Pendidikan Biologi Indonesia), 4(2), $151-$ 10. doi: https://doi.org/10.22219/jpbi.v4i2.5804

Koyama, A., \& Mizokamil, S. (2019). The effect of attitudes toward lectures on learning outcomes mediated by attitudes toward active learning. Educational Technology Research, 4(1), 69-76. doi: https://doi.org/10. 15077/etr.42137

Kurniyawati, F., Na'im, M., \& Fawait, A. (2019). Influence of problem based learning by using mind mapping observed by the prior knowledge level of students learning outcomes in the social studies. International Journal of Management and Administrative Sciences, 5(2), 15-22. Retrieved from https://repository. unej.ac.id/

Lau, K. W., \& Lee, P. Y. (2015). The use of virtual reality for creating unusual environmental stimulation to motivate students to explore creative ideas. Interactive Learning Environments, 23(1), 3-18. doi: https:// doi.org/10.1080/10494820.2012.745426

Lian, B., Kristiawan, M., \& Fitriya, R. (2018). Giving creativity room to students through the friendly school's program. International Journal of Scientific \& Technology Research, 7(7), 1-7. Retrieved from https:/l www.researchgate.net/profile/Muhammad

Lukitasari, M., Purnamasari, I., Utami, S., \& Sukri, A. (2019). Blended-problem-based learning: How its impact on students' critical thinking skills? JPBI (Jurnal Pendidikan Biologi Indonesia), 5(3), 425-434. doi: https://doi.org/10.22219/jpbi.v5i3.10048

Magana, A. J., Vieira, C., \& Boutin, M. (2018). Characterizing engineering learners' preferences for active and passive Learning methods. IEEE Transactions on Education, 61(1), 46-54. doi: https://doi.org/10.1109/ TE.2017.2740203

Mandernach, B. (2015). Assessment of student engagement in higher education: a synthesis of literature and assessment tools. International Journal of Learning, Teaching and Educational Research, 12(2), 1-14. Retrieved from http://mail.ijlter.org/index.php/ijter/article/view/367

Maurisa, A. M., \& \& Abdullah, H. (2016). Hubungan kemampuan membuat peta konsep dengan hasil belajar siswa di kelas XI pada materi pokok sistem ekskresi manusia. Jurnal Pelita Pendidikan, 4(2), 13-22. doi: https://doi.org/10.24114/jpp.v4i2.4017

Molenda, M. (2015). In search of the elusive ADDIE model. Performance Improvement, 54(2), 40-42. doi: https://doi.org/10.1002/pfi.21461 
Mwanda, G. (2017). Towards adoption of constructivist instructional approach in learning biology in secondary school students in Kenya: Addressing learner attitude. International Journal of Secondary Education, 5(1), 1-10. doi: https://doi.org/10.11648/j.ijsedu.20170501.11

Negoro, R. A., Hidayah, H., Subali, B., \& Rusilowati, A. (2018). Upaya membangun ketrampilan berpikir kritis menggunakan peta konsep untuk mereduksi miskonsepsi fisika. Jurnal Pendidikan (Teori dan Praktik), 3(1), 45. doi: https://doi.org/10.26740/jp.v3n1.p45-51

Ogonnaya, U. P., \& Abonyi, O. S. (2016). Effects of concept mapping instruction approach on students ' achievement in basic science. Journal of Education and Practice, 7(8), 79-84. Retrieved from https://eric. ed.gov/?id=EJ1095361

Ones, D. S., Dilchert, S., \& Viswesvaran, C. (2012). Cognitive abilities. (N. Schmidt, Ed.). Oxford: Oxford University Press. Retrieved from https://books. google.co.id/books?hl=id\&lr=\&id

Oumet, J. A., \& Smallwood, R. A. (2005). CLASSE: The class-level survey of student engagement. Journal of Assessment Update: Progress, Trends, and Practices in Higher Education, 17(6), 13-15. Retrieved from https://eric.ed.gov/?id=EJ790789

Rahmadani, W., Harahap, F., \& Gultom, T. (2017). Analisis faktor kesulitan belajar biologi siswa materi bioteknologi di SMA negeri se-kota Medan. Jurnal Pendidikan Biologi, 6(2), 279-285. doi: https://doi.org/ 10.24114/jpb.v6i2.6546

Richland, L. ., Frausel, R. ., \& Begolli, K. (2016). Cognitive development. In The SAGE encyclopedia of theory in psychology (pp. 143-146). California: SAGE Inc. doi: https://doi.org/10.4135/9781483346274.n50

Rotgans, J. I., \& Schmidt, H. G. (2011). Cognitive engagement in the problem-based learning classroom. Advances in Health Science Education, 16, 465-479. doi: https://doi.org/10.1007/s10459-011-9272-9

Safitri, D., Bachtiar, S., \& Rukman, W. Y. (2018). Students ' cognitive achievement, critical thinking skills, and metacognitive. European Journal of Education Studies, 5(4), 248-258. doi: https://doi.org/10.5281/zeno do. 1482095

Safitri, M., Yennita, Y., \& Idrus, I. (2018). Upaya meningkatkan aktivitas dan hasil belajar ipa siswa melalui penerapan model problem based learning (PBL). Diklabio: Jurnal Pendidikan Dan Pembelajaran Biologi, 2(1), 103-112. doi: https://doi.org/10.33369/diklabio.2.1.103-112

Sasinggala, M. (2017). Concept map learning strategy, with a guided discovery approach to metacognitive skills IPA biology on primary school biology at Siau Island sitaro regency, 2(5), 34-40. doi: https:/l doi.org/10.22271/educationjournal

Savory, P., Goodburn, A., \& Kellas, J. K. (2012). Measuring classroom engagement by comparing instructor expectationswith students' perceptions. The International Journal for the Scholarship of Teaching and Learning, 7(1), 1-21. Retrieved from https://digitalcommons.unl.edu

Sofyan, H., \& Komariah, K. (2016). Pembelajaran problem based learning dalam implementasi kurikulum 2013 di SMK. Jurnal Pendidikan Vokasi, 6(3), 260. https://doi.org/10.21831/jpv.v6i3.11275

Surani, S., \& Suryani. (2015). Peningkatam aktifitas belajar siswa menggunakan metode eksperimen dalam pembelajaran IPA di sekolah dasar. Jurnal Pendidikan dan Pembelajaran Khatulistiwa, 4(2), 1-12. Retrieved from http://jurnal.untan.ac.id/index.php/jpdpb/article/view/12676/11486

Tarmizi, R. A., Tarmizi, M. A. A., Lojinin, N. I., \& Mokhtar, M. Z. (2010). Problem-based learning: engaging students in acquisition of mathematical competency. Procedia-Social and Behavioral Sciences, 2(2), 4683-4688. doi: https://doi.org/10.1016/j.sbspro.2010.03.750

Van Amburgh, J. A., Devlin, J. W., Kirwin, J. L., \& Qualters, D. M. (2007). A tool for measuring active learning in the classroom. American Journal of Pharmaceutical Education, 71(5), 85. doi: https://doi.org/10.5688/aj 710585

Widodo, H. (2016). Potret pendidikan di Indonesia dan kesiapannya dalam menghadapi masyarakat ekonomi asia (MEA). Cendekia: Journal of Education and Society, 13(2), 293. doi: https://doi.org/10.21154/cen dekia.v13i2.250

Yang, L., Zhang, Y., Chen, J., Zhang, S., \& Chen, D. Z. (2017). Suggestive annotation: A deep active learning framework for biomedical Image segmentation (pp. 399-407). doi: https://doi.org/10.1007/978-3-31966179-7_46

Yanuarta, L., Waluyo, J., \& Suratno. (2014). Penerapan model pembelajaran kooperatif tipe think, talk, write (TTW) dengan teknik talking stick dalam meningkatkan karakter dan hasil belajar IPA-biologi. Pancaran Pendidikan, 3(1), 1-10. Retrieved from https://jurnal.unej.ac.id/index.php/pancaran/article/view/724 